\title{
Savoir s'y prendre : la gestion collective des connaissances et la mémoire individuelle
}

Jean-Pierre Poitou

\section{(2) OpenEdition}

1 Journals

Édition électronique

URL : https://journals.openedition.org/tc/459

DOI : $10.4000 /$ tc. 459

ISSN : 1952-420X

Éditeur

Éditions de l'EHESS

\section{Édition imprimée}

Date de publication : 1 novembre 1997

ISSN : 0248-6016

\section{Référence électronique}

Jean-Pierre Poitou, «Savoir s'y prendre : la gestion collective des connaissances et la mémoire individuelle », Techniques \& Culture [En ligne], 28| 1997, mis en ligne le 28 octobre 2005, consulté le 29 septembre 2022. URL : http://journals.openedition.org/tc/459 ; DOI : https://doi.org/10.4000/tc.459

Ce document a été généré automatiquement le 29 septembre 2022.

Tous droits réservés 
Savoir s'y prendre : la gestion collective des connaissances et la mémoire individuelle

Jean-Pierre Poitou 